\title{
CULTURE AND COUNTRY TOWARDS CHILD RIGHT IN NEPAL
}

\author{
Apar Kumar Lamsal \\ Lecturer, Culture Department \\ PG Campus Biratnagar, Tribhuvan University Nepal \\ aparkumar@yahoo.com
}

\begin{abstract}
It has scientifically proved that childhood is the most creative period of human life. It is the basic building block of human development. One of the famous humanitarian personalities of the world, Mahatma Gandhi rightly said "If we are to have real peace, we must begin with the children." It is necessary to make this period safer, creative. But it is worldwide threatening to the children from the terrorism and different kinds of child abuse like child labor, child trafficking, gender discrimination, prohibition from the education etc. Nepal is one of the countries which are not out of them. It is the time for thinking how to safe children. Though Nepal has already formulated laws regarding the child right, but they are only "paper tiger". So, it is necessary to implement the existing laws and abolish the all kind of discrimination and child abuse and follow the international convention relating to child right.
\end{abstract}

Key words: child, culture, constitution, convention, legal provision, right,

\section{Preamble}

Childhood means more than just the time between birth and the attainment of adulthood. It refers to the state and condition of a child life: to the quality of those years. Children of the present are the citizen of the future. They are the foundation stone of the upcoming society and nation. Our future depends on them but their present depends on us. But, children of the world are facing different kinds of problem. They are suffering from the discrimination by the state and society. In this regards United Nations and other organizations have tried to save the life of children in an organized way through legally and other means. Likewise, different countries have also made a legal provision for the protection of child life and dignity. Children's rights are the human rights of children with particular attention to the rights of special protection and care afforded to minors, including their right to association with both parents, human identity as well as the basic needs for food, universal state-paid education, health care and criminal laws appropriate for the age and development of the child, equal protection of the child's civil rights, and freedom from discrimination on the basis of the child's race, gender, sexual orientation, gender identity, national origin, religion, disability, color, ethnicity, or other characteristics. Interpretations of children's rights range from allowing children the capacity for autonomous action to the enforcement of children being physically, mentally and emotionally free from abuse, though what constitutes "abuse" is a matter of debate (wikipedia.org/wiki/Children\%27s_rights ). In this paper, a short description of cultural practices in the regard of child and legal provision to protect the right of child in Nepal has been given.

\section{Methodology}

This paper is prepared mainly on the basis of literary material. It is just an account of the historical overview of legal provision on the matter of child right. Some cultural practices relating to the status of child are known by the researcher as a native people. That is why, it can be said that 'experience' as a primary source is used in this research. So, this research is also based on retrospective covert observation. It is a descriptive study. 


\section{Cultural Practices}

There is one proverb prevailing in Nepal that 'balbalika bhaneka gilo mato jastai hun' means children are like a wet clay, that can be shaped as we wish'. Childhood, therefore, should be cared, loved, protected and fulfilled other necessary requirements by their patents and the state. But, there is a problem regarding the right of children in Nepal. Discrimination between male and female child is the culture of Nepalese societies. According to Hindu philosophy, without male issue person can't go sworg after their death. Traditional beliefs have contributed significantly in many Nepalese families as a result of which sons are more preferred. Religious, social and economic compulsions regard sons as not only valuable but also an indispensable asset whereas daughters are taken as financial burden to their parents. People give low priority in education, health and other basic requirements to female child than male child. Above all, discrimination between children on the basis of their work, class status, and caste status is common practices in Nepalese society. Khate balbalika or street child is another big problem in Nepal. Likewise slavery, trafficking, household worker, child labor in different industry, rape etc are threatening the modern humanitarian society. The poor society of Nepal believes their children as their property while rich families feel proud themselves when they have children as a household labor. Children are also being affected by dalit (Caste- based discrimination) culture. Dalit children not permitted to drink water and eat food with the so-called upper caste; rude manner of addressing to them; putting dalit children in separate lines in school; throwing school mid-day meals to these children wrapped in paper while serving it to others on a plate. They have involved in huge number as a bonded labor, commercial sex worker, and activities similar to slavery.

\section{Legal Provision}

Realizing the importance of childhood and state's responsibility toward betterment of children, the concept of child right is initiated. First time in history, in 1924 under the League of Nations, the Declaration of the Rights of the Child 1924, was made with five principles which recognized the child rights in international spare. In 1959, the UN General Assembly declared the Declaration of the Rights of the Child 1959 with ten fundamental principles. In 1989 the UN General Assembly adopted the Convention on the Rights of the Child (CRC) 1989 which is ratified by most of the member States with zero against vote. The CRC holds binding forces. It is a great departure in field of Rights of the Child. The CRC has made clear principles and right of the child for survival, development, protection and participation and obligation to parent(s)/family and the state. The Government ratified the Convention on the Rights of the Child (CRC) on the 14th of September 1990 and adopted legislative, administrative and other measures with a view to incorporating the rules of the Convention in its legislation. After the Maoist insurgency, comprehensive peace accord among the political parties made a commitment for the right of children against sexual abuse, child labor, right against any kind of violence.

The Nepal has a short history of modern positive law. Code of Laws 1853 (Muluki Ain, 1910 B.S.) was the first one. The Code is still one of the major law instruments in the Nepalese legal sphere. The Code is divided into different headings, Mahal. However there is no separate Mahal for children, there are some provisions/rights specific to them. Children's Act 1992 is the first act solely dedicated to the rights of the child and their concern. The Act recognizes the rights of child to identity; non-discrimination; non-exploitation; protection; education and development; and juvenile justice to upbringing, development and protection of the child. Furthermore, the child labor issued has been addressed in Child Labor (Prohibition and Regulation) Act 1999. Although Nepal already had ratified the Convention on the Rights of the Child 1989 and earlier human right \& labor right instruments, the respective domestic initiations were not undertaken properly. Following the ratification of the Convention of the Rights of the Child Nepal has enacted the Children's Act 1992. 
Some major provisions of the Constitution 1990 in respect to child rights are Right to nationality (every child who is found within the Kingdom of Nepal and the whereabouts of whose parents are not known shall, until the father of the child is traced, be deemed to be a citizen of Nepal by descent), Right to non-discrimination (Constitution recognizes right to non-discrimination and special consideration to child), Right to culture and development (community's right to operate schools up to the primary level in its own mother tongue for imparting education to its children)., Right to actions taken in their best interests (the State shall make necessary arrangements to safeguard the rights and interests of children and shall ensure that they are not exploited, and shall make gradual arrangements for free education; and the State shall pursue such policies in matters of education, health and social security of orphans, helpless women, the aged, the disabled and incapacitated persons, as well as ensure their protection and welfare).

The Children's Act 1992 is first law of land about rights of the child. Right to name \& identity (child's right to name), Right to maintenance and upbringing, education and health (parents and government are obligated to make arrangements to bring up the child and to provide education, health care, sports and recreation facilities to the child according to the economic status of their family.), Right to non-discrimination (the child's right of non discrimination between son and daughter; between sons and daughters; between child born out of wedlock and lawful wedlock; and between natural and adopted son \& daughter), Right to protection from torture and rigorous punishment (No child shall be subjected to torture or cruel treatment), Right to juvenile justice and limited criminal liability (The child below the age of 10 is not liable to any type of punishment on his criminal activity; the child above 10 yrs and below 14 yrs who commits an offence which is punishable with fine under law, he shall be warned and explained and if the offence is punishable with imprisonment, he shall be punished with imprisonment for a term which may extend to six months depending on the offence; and if the child who is above 14 years and below 16 years commits and offence he shall be punished with half of the penalty of the penalty to be imposed under law on a person who has attainted maturity), Right to non- exploitation (immoral professional exploitation including child pornography and drug abuse) etc. In this way, Nepal has followed the principles and provisions of UN Convention on the Rights of the Child 1989 while making domestic law, the Children's Act 1992.

Interim constitution of Nepal 2007 is remarkable in many senses. It made a step forward to ensure citizenship certificate to many whose father was unknown declining from the traditional provision influenced by patriarchal structure of Nepalese society. The provision providing the rights to have citizenship certificate to all those born till the date mid April of 1990 and have been residing permanently in Nepal ended the uncertainty and statelessness of many youths. Article 13 (3) powered the state to make special provisions by law for the protection, empowerment and advancement of the interests of weaker sections, that also included children. Right to reproductive health, equal rights of son and daughter to ancestral property as fundamental rights can also be taken as progressive steps towards ensuring child rights. Providing rights of child explicitly as fundamental rights is one of the remarkable steps. These provisions carry some landmark concepts of child rights, such as, right to identity, right to health, right against exploitation and right to security. Likewise, Juvenile Justice Procedure Regulation 2007 has provided provision relating to investigation and prosecution of juvenile delinquents. According to them, the provisions like no inquiry more than one hour at a time and in night, hearing by sociologist, psychologist and child-expert, medical check-up of arrestee, investigation in the father, mother or guardian are remarkable.

Above all, following are the legal provision that indirectly address the child right:

Breast Milk Substitutes Control Act (1992), District Development Committee Act (1991), Insurance Act (1992), The Labor Act (1992), Local Election Act (1991), Municipality Act (1991), Social Welfare Act (1992), Village Development Committee Act (1991), Civil Service Regulation (1993), 
Education Regulation (1992), Labour Regulation (1993), Police Regulation (1992), Tea Garden Labour Regulation (1993), Beginning Prohibition Act (1961), Birth and Death Registration Act (1976), Citizens Rights Acts (1964), Civil Liberties Acts (1954), Contract Acts (1966), Curse and Defamation Act 1959, Drug Abuse Control Act (1976), Education Acts (1971), Evidence Acts (1974), Hotel Management and Liquor Sales \& Distribution Control Acts (1966), Human Trafficking Control Act (1986), Income Tax Act (1974), Local Administration Act (1971), Marriage Registration Act (1971), Muluki Ain General Law (1963), Nepal Citizenship Act (1963), Police Act (1956), Prison Act (1962), Provident Fund Act (1962), Small Pox Control Act 1963, Compensation Rules (1963), Demographic Statistics Registration Regulation (1977), Government Hostel Regulation (1972), Money Other Regulation (1974), Passport Rules (1970), Post Office Saving Bank Regulation (1976), Prison Regulation (1963), Royal Army New Recruitment Rules (1962), Small Pox Control Rules (1966), Sucking Baby Maintenance Rule (1962), Young Boys Recruitment and Condition of Services Rules (1971), Disabled Protection and Welfare Act (1982)

\section{Conclusion and Recommendation}

This above mentioned account shows that in the field of child right protection, world organizations as well as Nepali state has made some contribution but the scenario of children status is very bad. Still they are suffering from discrimination and backwardness in educational, health, and other sector. So, state should strictly follow legal provision. In Nepal their implementation remains a difficult challenge in the face of limited institutional and human resources. UNICEF, the international organization for the child right and other NGOs and INGOs are working in Nepal to protect the child right. With the development of People's education level and political awareness, gender discrimination has been decreasing. But in practice, the problem is not abolished. So, first of all, it is necessary to establish a culture of child right.

\section{Reference}

Interim constitution 2007

wikipedia.org/wiki/Children\%27s_rights 